PRACE NAUKOWE Akademii im. Jana Długosza w Częstochowie Kultura Fizyczna 2014, t. XIII, nr 2, s. 157-166

http://dx.doi.org/10.16926/kf.2014.13.10

\author{
Ivan UHER*, Anna PILIS ${ }^{* *}$, Eva LITAVCOVÁ***
}

\title{
Functional Fitness, Quality of Life and Living in the Moment, Senior Population Study
}

\begin{abstract}
It is well known that our internal state affects our ability to perform everyday tasks. Some studies [6], [17] found that the admonition to live for a present is more important than we imagined. A human mind is a wandering mind, and a wandering mind is an unhappy mind [13]. The objective of the current study was to determine how living for a present relates to quality of life and functional fitness of senior cohorts $(\mathrm{n}=38 \mathrm{~F}$. mean age $=75,6$ years $(\mathrm{SD} \pm 9.4)$ that exercise regularly. Older adults completed a functional fitness test battery, quality of life and living for a present questionnaire. Living for a present was associated with age of participants, quality of life and BMI. No statistical significance was found between living for a present, functional fitness and medication use. The results support the role of living for a present as a correlate of age, BMI and quality of life. These data substantiate that living in a present could serve as an important course for better existence. In any means our study is not conclusive. Further study are needed to clarify this complex issue as living for a present no doubt represents.
\end{abstract}

Keywords: living for a present, functional fitness, quality of life domains, elderly women.

\section{Introduction}

\section{Functional fitness}

There is no doubt that the older population in our society is rapidly increasing. However the expected lifetime without long-standing illness and better quality of life increased only modestly. In number of developed countries older cohorts generate the highest health care expenditures. Although physical fitness traditionally has been associated more with younger age groups than with older

\footnotetext{
* ÚTVŠ UPJŠ Košice.

** Jan Dlugosz University in Czestochowa, Poland.

${ }^{* * *}$ FMPU PU v Prešove.
} 
people, it is most crucial during the later senior years. Older adults tend to be less active with advancing age, even though it is well known that physical activity is important for independent living, prevention of chronic health problems, and quality of life [9], [4]. An active lifestyle is important in preventing decreases in functional capacity and, indirectly quality of life [22], [18]. Brach et al. demonstrated a significant relation between physical activity during a 14-year period and current functional status in older women. Author claims that physical activity has a significant role in maintaining functional capacity. In addition to age, lessening of physical activity also contributes to the decline in functional capacity and quality of life. New evidence is accumulating that exercise had profound benefits for brain function. Physical activity improves cognition and might delay age-related memory decline [7], [11].

\section{Living for present}

Numbers of studies in psychology, economics, and behavioral neuroscience typically measure the effects of internal state on perception by manipulating specific factors such as arousal, attention, or motivation and comparing behavior performance between blocks of behavioral trials. Yet no study investigating living for a present as a correlate to quality of life. Beyond that, it is well known fact that our internal state affects our ability to perform even basic tasks. Behavioral studies are indicating that our minds wander away from present task as much as half the time [13]. Because fluctuations in cognitive factors such as attention, arousal, living for a present (LFP), or motivation are difficult to control or even measure, their effects on behavior have been difficult to assess. Fluctuations in internal state can in principle affect our behavior in systematic way. Authors [13] found that the participant's mind wandered frequently, and reported that their mind was wandering $47 \%$ of the time were contacted. Author claim, that when people said that their mind was wandering, they also said that they were less happy. No matter how hard subjects concentrate on a task at hand, their minds wander claims [20], [5]. Contrary [16] argue that "living for a present" may be impossible. The brain has to keep track of decisions and the outcomes they produce. Author predicted that neuronal correlated of meta - cognition resided in the same brain areas responsible for cognition in cortex - a part of the brain linked with personality expression, decision making, and social behavior.

\section{Quality of life}

It has been emphasized over and over that Quality of Life (QoL) is an extremely complex, abstract, and scattered concept difficult to define and has a high impact on research and practice [25]. QoL is a key concept in environmental, social, medical and psychological sciences, as well as in public policy and in the minds of the population at large, nevertheless, there is no consensus regarding the definition of QoL. In our study we employ [15], [2] models. Obviously, self-report is 
the most direct measure for assessing subjective appraisal for any of the conditions present in QoL. QoL is mainly reduced to health, and several health measures have been taken as QoL measures. When several domains were considered, QoL was mostly reduced to the individual's subjective appraisal of those domains. However, none of above mentioned subjective examinations included living for a present as a QoL factor.

The objective of our study was to determine how living for a present relates to quality of life and functional fitness in community - dwelling alder women. We hypothesized that living for a present would be significantly associated with functional fitness and QoL.

\section{Methods}

\section{Subjects}

The subjects $(\mathrm{n}=38 \mathrm{~F}$. mean age $=75,6$ years $(\mathrm{SD} \pm 9.4)$, were recruited from older adults living in the Košice municipality region. All of the adults were given information about the study. Older adult's volunteers who fit the inclusion criteria were evaluated. Inclusion criteria were: aged $\leq 60$ years that were physically independent, community - dwelling, participating regularly in structural physical activity minimum for 5 years continuously.

\section{Procedure}

The functional fitness evaluation (SFT-test ) [21] included the body mass index in kilograms per meter square of height (BMI $\mathrm{kg} / \mathrm{m}^{2}$ ), the "Chair stand test" for lower body strength, the "Arm curl test" as a general measure of upper-body strength, the "8-feet up-and-go test" for agility/dynamic balance. The "2-minute step test" as a measure of aerobic endurance. "Chair sit-and-reach test" to assess lower-body flexibility, particularly hamstring flexibility and "Back scratch test" to evaluate upper-body flexibility that measure especially shoulder flexibility. Before the (SFT-test) execution standard explanation was provided. The results were comparing to the normative and criterion standards created for different age groups in senior population.

The $(\mathrm{QoL})$ questioner was measured by the medium of standardize most widely used Bref - World Health Organization Quality of Life Questioner (WHOQOL-BREF). The (WHOQOL-BREF) and its Czech version (WHOQOL-BREF) [8] are producing a quality of life profile. Test derives four domain scores (physical health, psychological, social relationships and environment). The four domain scores with total of 26 questions denote an individual's perception of quality of life in each particular domain. Domain scores are scaled in a positive direction (i.e. higher scores denote higher quality of life). The mean 
score of items within each domain is used to calculate the domain score. Mean scores are then multiplied by 4 in order to make domain scores comparable with the scores used in the WHOQOL - 100 long version. The obtained scores were transformed to range between 4-20 comparable with the (WHOQOL-100). The questioner was self-administered with some interviewer - assistance.

The living for a present was assessed with non-standardize Living for Present (LFP) questioner. The total of 28 questions was focus on living for the moment. Domain scores are scaled in a positive direction Likert five point scale 1-5 (disagree, somewhat disagree, neither yes or no, somewhat agree, agree). The aggregated mean score was used to calculate overall score, higher scores represent better outcomes.

\section{Statistical analysis}

We used the Program Statistical (P. 12.0) for statistical analysis. The relationships between Living for a present, Functional fitness and Quality of Life were evaluated via regression Pearson correlation coefficient. Some demographic data (age, place of residence, marital status, education), (means $\pm \mathrm{SD}$ ), and minimum - maximum values have been added. Other demographic characteristics are given as numbers and percentages.

\section{Results}

The selected characteristics of the subjects in the physically active group of women with a mean age 75.6 yrs. $(\mathrm{SD} \pm 9.4)$ are displayed in Table 1. Correlations in all twelve domains $(\mathrm{p}<0.05)$ indicated that only two out of twelve domains were significantly correlated with living for a present. The findings are supportive of the position that participant's age and BMI measures play role in living for a present. Ad verso no association was found between living for a present in comparison with functional fitness in all SFT subtests, years of participation in regular exercise and medication usage.

Table 1. Association between living for a present and age, somatic parameters, BMI, SFT test, years of exercise and the use of medication.

\begin{tabular}{|c|c|c|c|c|c|c|c|c|}
\hline \multirow[b]{3}{*}{ Variables } & \multicolumn{8}{|c|}{ Correlation (data) } \\
\hline & \multicolumn{8}{|c|}{$\mathrm{p}<, 05 \quad \mathrm{~N}=38$} \\
\hline & Age & Hight & $\begin{array}{c}\text { Body } \\
\text { Weight }\end{array}$ & BMI & $\begin{array}{c}\text { Chair stand } \\
\text { test }\end{array}$ & $\begin{array}{c}\text { Arm curl } \\
\text { test }\end{array}$ & $\begin{array}{c}\text { 2-min. } \\
\text { step test }\end{array}$ & $\begin{array}{l}\text { Chair sit } \\
- \text { and - } \\
\text { reach test }\end{array}$ \\
\hline \multirow[t]{2}{*}{$\begin{array}{l}\text { Living for } \\
\text { a present }\end{array}$} &, $4354^{*}$ & ,2978 &,- 1866 &,$- 3514^{*}$ &, 0681 & ,1376 & ,0181 &,- 0232 \\
\hline & $\mathrm{p}=, 006$ & $\mathrm{p}=, 069$ & $\mathrm{p}=, 262$ & $\mathrm{p}=, 031$ & $\mathrm{p}=, 685$ & $\mathrm{p}=, 410$ & $\mathrm{p}=, 914$ & $\mathrm{p}=, 890$ \\
\hline
\end{tabular}


Table 1. Association... (cont.)

\begin{tabular}{|l|c|c|c|c|}
\hline \multirow{2}{*}{ Variables } & \multicolumn{4}{|c|}{$\begin{array}{c}\text { Correlation (data) } \\
\mathrm{p}<, 05\end{array} \mathrm{~N}=38$} \\
\cline { 2 - 5 } & Back scratch test & $\begin{array}{c}\text { 8-feet up - and - } \\
\text { go test }\end{array}$ & $\begin{array}{c}\text { Years of regular } \\
\text { exercise }\end{array}$ & $\begin{array}{c}\text { Medication } \\
\text { use }\end{array}$ \\
\hline Living for a present &, 2428 &, 0947 &, 3036 &,- 3050 \\
\hline & $\mathrm{p}=, 142$ & $\mathrm{p}=, 572$ & $\mathrm{p}=, 064$ & $\mathrm{p}=, 063$ \\
\hline
\end{tabular}

* difference statistically significant; $\mathrm{p}<0.05$

Pearson $r$ correlation coefficient

Table 2. Association between living for a present and four WHOQOL-BREF domains

\begin{tabular}{|l|c|c|c|c|}
\hline \multirow{2}{*}{ Variables } & \multicolumn{4}{|c|}{$\begin{array}{c}\text { Correlation (data) } \\
\mathrm{p}<, 05 \\
\mathrm{~N}=38\end{array}$} \\
\cline { 2 - 5 } & $\begin{array}{c}\text { Physical } \\
\text { health }\end{array}$ & $\begin{array}{c}\text { Psychological at- } \\
\text { tributes }\end{array}$ & $\begin{array}{c}\text { Social } \\
\text { relationships }\end{array}$ & Evironment \\
\hline Living for a present &, 2706 &, $4968^{*}$ &, $7411^{*}$ &, $4227^{*}$ \\
\hline & $\mathrm{p}=, 100$ & $\mathrm{p}=, 002$ & $\mathrm{p}=, 000$ & $\mathrm{p}=, 008$ \\
\hline
\end{tabular}

* difference statistically significant; $\mathrm{p}<0.05$

Pearson $r$ correlation coefficient

Table 2 displays the comparison between living for a present and four quality of life domains. As it can be seen, living for a present was significantly associated with all WHOQOL-BREF model construct excluding physical health, were we did not found statistical significance. In summary, being more physically active does not imply live more in the moment. Contrary psychological traits like (body image, feelings, self-esteem, beliefs, concentration), Environmental traits (safety and security, leisure activity, recreational opportunities, home environment) and Social relationships (personal relationships, social support) significantly correlates with living for a present.

\section{Discussion}

The findings of our study suggest that association exists between living in for a present age of the participants, quality of life and BMI. No statistical significance was found between living for a present and functional fitness, years of participation in regular exercise and the medication use.

Even though a causality cannot be assessed due to the cross-sectional design of the study, our results, showing that people with higher BMI, live less for a present than people with lower BMI values. Prior research has shown that the 
prevalence of depression and depressive mood among people with higher BMI values is increased compared to the normal population of the same age [1], [10], [19]. Our results, are in line with these findings, as more we identify with our thinking, our likes and dislikes, judgments and interpretations the less we live in a present. Kolotkin et al. claim that progression to obesity would likely result in adverse effects on mental health. In summary, we found that quality of life is affected by increasing overweight levels, in the absence of overt obesity. Our study shows that overweight non-obese individuals also display impairment in quality of life. It is important therefore that such aspects are considered in the health management of overweight individuals, not only to improve health related and functional related fitness, but also to work on mental state (live for a present) that halt a consequent progression to obesity.

Older participants in our study were living more for a present than relatively younger participants. This finding may be due to two different reasons. First of all as we get older we focus our attention inwards (we have amply of time, have more experience, become less judgmental, enjoying more present experience, think less feel more and so forth) and that reality to some extend can contribute to living for a present or else more here and now. Secondly, older person are more likely to experience themselves as part of humanity, as part of a greater universe "one with everything". In that respect may have less negative thoughts that in reality mostly concern the past or the future.

QoL is the product of the dynamic interaction between external conditions of and individual's life and the internal perceptions of those conditions, where in our view live for a present plays crucial role. We understand that quality of life cannot be equated simply with the health status, life style, life satisfaction, mental state or well-being, we recognize of the multi-dimensional nature of quality of life. We believe and our results just prove that quality of life is dominantly influence by living in a present. Reminiscing, thinking ahead or daydreaming tends to make people miserable, even when they are thinking about something pleasant [13]. Human spend a lot of time thinking about what is not going on around them. Contemplating events that happened in the past, might happen in the future, or may never happen . Indeed, mind wandering appears to be the human brains default mode of operation [17], [24], [23]. In that respect mind wandering in general can be the cause, not the consequence of our unhappiness. In fact, how often our minds leave the present and where they tend to go is a better predictor of our happiness than the activities in which we are engaged. We are coming to the conviction that mind-wandering is a significant predictor of peoples happiness.

Even though, happiness may not be enough as a measure of quality of life as can be seen from the case of the 'happy poor'. It is clear, though, that there is more to quality of life than just subjective attributes such as happiness or satisfaction. There are also objective qualities too, and some of these, such as suffi- 
cient nutrition, a non-hazardous environment, and a long and healthy life are universally, or virtually universally uncontroversial as components of quality of life, that we are aware off.

In that context [12] argue, that people do not generally know how happy they are, and they must construct an answer to that question whenever it is raised. He claims that the starting point should not be people's subjective views about how happy they are but instead objective measures of those sensations that are associated with the real-time feeling of happiness in other words, objective happiness.

Despite above mentioned, we claim that the power to control our inner state is crucial on the way to happiness and quality of life. To accept what happen around us, to forgive, to seen from a higher perspective. There will be no good or bad in our life anymore. We have to realize that we are responsible for our inner state of being nobody else is. The moment we realize this we have broken the attachment and that is true happiness. Attention is the key to transformation. Attention does not mean that we start thinking about it. It means to just observe the emotion, to feel it fully, and so to acknowledge and accept it as it is. We should practice of body awareness that will bring inner peace and that bring above everlasting happiness and quality of life. Is there any scientific evidence of this? We should try it and we will be the evidence.

There are important differences in the design of our study and of other investigations conducted on the association between functional fitness and quality of life in the elderly population. We used performance based measures of physical function. This approach minimizes bias when studying an elderly population. Further, we analyzed the magnitude and significance of the association between each SFT sub-test and QoL domain parameters, rather than using complex summary measures of functional fitness and quality of life. The SFT test, QoL and LFP questionnaires were specifically selected with the aim of measuring the association between chosen domain, they are brief, simple to use, and do not require sophisticated tools to be measured or analyzed. Lastly there is no study interconnecting living for a present with quality of life and functional fitness.

Some weakness of our study have to be acknowledged: While our results cannot be generalized to populations with physical limitations, given that these individuals were excluded at baseline, they do apply to the majority of elderly who are independent and community based. Further our data are not able to assess causality of the association between living for a present, functional fitness, quality of life and the BMI. But they confirm the relationship and emphasized the influence of living in a moment on age of the participants, obesity and quality of life. Moreover living for a moment questionnaire needs to be standardized in order to demonstrate its relevance. 


\section{Conclusion}

It has been known for a long time that our inner state influences our quality of life. We are conditions to believe that happiness comes with struggle. Contrary our position is that quality of life and happiness comes with our realization of what is and that we can found in the present. In order to understand this complex issue we will need a reliable instrument that can measure just that. Our findings give support to the notion that living for a present can be valuable indicator of happiness and better quality of life. Therefore, incorporating this domain to the prospective studies investigating happiness and quality of life can be valuable. From our perspective more research is needed to provide evidence that living for a present is crucial for happiness and quality of life.

\section{Bibliography}

[1] Backenstrass M., Frank A., Joest K., Hingmann S., Mundt C., Kronmuller K.T. (2006): A comparative study of nonspecific derpesseive symptoms and minor depression regarding functional impairment and associated characteristics in primary care. Compr. Psychiatry, 47, 35-41, http://dx.doi.org/ 10.1016/j.comppsych.2005.04.007.

[2] Ballesteros R., Santacreu I.M. (2010): Aging and quality of life, [in:] Stone J.H., Blouin M. (eds.): International Encyclopedia of Rehabilitation.

[3] Brach J.S., Fitzgerald S., Newman A.B., Kelsey S., Kuller L., VanSwearingen J.M., Kriska A.M. (2003): Physical activity and functional status in community -dwelling older women. Arch Inter. Med., 163, 2565-2571, http://dx.doi.org/10.1001/archinte.163.21.2565.

[4] Brill P.A. (2004): Functional fitness in older adults. Human Kinetics, 12, 3-8.

[5] Christoff K., Gordon A.M., Smallwood J., Smith R., Schooler J.W. (2009): Experience sampling during fMRI reveals default network and executive system contributions to mind wandering. Proc. Natl. Acad. Sci., 106, 87198724, http://dx.doi.org/10.1073/pnas.0900234106.

[6] Cohen R. (2012): When attention wanders. Science Magazine, 338 (6103), 58-59, http://dx.doi.org/10.1126/science.1229552.

[7] Cotman C.W. (2007): Exercise builds brain health. Key roles of growth factor cascades and inflammation. Trends Neurosci., 30, 464-472, http://dx. doi.org/10.1016/j.tins.2007.06.011.

[8] Dragomirecka E., Bartoňová J. (2006): World Health Organization Quality of Life Assessment. Vydalo, Psychiatrické centrum Praha, 87-90.

[9] Hardman A.E., Stensel D.J. (2003): Ageing, therapeutic exercise and public health. [in:] Physical activity and health. The evidence explained. Routledge Taylor and Francis Group, London, 241-54. 
[10] Herva A., Laitinen J., Miettunen J., Veijola J., Karvonen J.T., Laksy K., Koukamaa M. (1966): Obesity and depression: results from the longitudinal Northern Finland. Birth Cohort Study. Int. J Obes., 30, 520-527.

[11] Hillman C.H. (2008): Be smart, exercise your heart: exercise effects on brain and cognition. Nat. Rev. Neurosci., 9, 58-65, http://dx.doi.org/10. 1038/nrn2298.

[12] Kahneman A., Tversky A. (1999): Choices, Values and Frames. (Edu.) New York. Cambridge University Press and the Russell Sage Foundation.

[13] Killingsworth M.A., Gilbert D.T. (2010): A wandering mind is a unhappy mind. Science, 330-332, http://dx.doi.org/10.1126/science.1192439.

[14] Kolotkin R.L., Meter K., Williams G.R. (2001): Quality of life and obesity. Obes. Rev., 2, 219-229, http://dx.doi.org/10.1046/j.1467-789X.2001.00040.x.

[15] Lawton M.P. (1991): A multidimensional view of quality of life in frail elders. [in:] Birren E. (ed.): The concept of quality of life in the frail elderly. San Diego: Academic Press, 3-27.

[16] Middlebrooks P. G., Sommer M. A. (2012): Neuronal Correlates of Metacognition in Primate Frontal Cortex. Neuron, 75 (3), 517-530, http://dx.doi. org/10.1016/j.neuron.2012.05.028.

[17] Nauert, R. (2010): Live in the moment or be unhappy. Psy.D., 12-17.

[18] Nemček D. (2010): Úroveñ vybraných pohybových schopností žien v staršom veku. Bratislava, SZRTVŠ, 115-118.

[19] Potašová A., Golecká L. (2003): Ako zvládat' nepríjemnosti. Program na podporu akomodačnej flexibility, inšpirovaný zásadami pozitívneho poradenstva a prevencie depresií. Ústav experimentálnej psychológie SAV, Bratislava.

[20] Raichle M.E., MacLeod A.M. Snyder A.Z., Powers W.J., Gusnard D.A., Shulman G.L. (2001): A default mode of brain function. Proc. Natl. Acad. Sci., 98, 676-682, http://dx.doi.org/10.1073/pnas.98.2.676.

[21] Rikli B., Jones J. (2013): Senior Fitness Test Manual - 2 Edition. Pub. Human Kinetics, 13, 200-203.

[22] Spirduso W.W., Francis K.L., MacRae P.G. (2005): Physical dimentions of aging. 2th edition. Human Kinetics, 373-277.

[23] Šulc I. (2010): Obezita - zmeny somatických parametrov u žien. In Telesná výchova, šport, výskum na univerzitách. Bratislava, 238-242.

[24] Šulc I. (2012): Vplyv životného štýlu poslucháčov. UPJŠ Košice na zmenu telesnej hmotnosti a kvalitu zdravia. In Od výskumu k praxi. Bratislava, 298-302.

[25] Walker A. (2005): A European Perspective on quality of life in old age. European Journal of Aging, 2, 2-13, http://dx.doi.org/10.1007/s10433-005$\underline{0500-0 .}$. 